\title{
ANALISIS NILAI MORAL NOVEL DAUN YANG JATUH TAK PERNAH MEMBENCI ANGIN KARYA TERE LIYE
}

\author{
Dinda Nurul Qoyyimah, Fauziah Suparman. \\ dindanurulqoyyimah@gmail.com; fauziahsuparman@live.com \\ Universitas Muhammadiyah Sukabumi
}

\begin{abstract}
Abstrak. Dalam karya sastra, salah satunya adalah novel seringkali pengarang atau penulis menyajikan nilai-nilai yang dapat diterapkan oleh pembaca dalam kehidupan, salah satunya yaitu nilai moral. Nilai moral merupakan suatu ukuran untuk menilai baik dan buruknya suatu perbuatan yang dapat dijadikan sebagai pedoman kehidupan manusia. Penelitian ini bertujuan untuk mendeskripsikan analisis nilai moral novel Daun Yang Jatuh Tak Pernah Membenci Angin karya Tere Liye. Jenis penelitian ini yaitu deskriptif kualitatif yang berarti penulis mengkaji dan menganalisis novel dengan menggunakan metode deskriptif. Hasil dari penelitian ini menghasilkan beberapa kesimpulan nilai moral novel yang mencakup empat aspek, yakni: (a) hubungan manusia dengan diri sendiri, meliputi mengakui kesalahan, berpendirian teguh, sedih, benci, menepati janji, dan bijaksana; (2) hubungan manusia dengan manusia lain, meliputi kasih sayang, menghormati orang tua, peduli, gemar menolong, dan ramah; (3) hubungan manusia dengan lingkungan alam, meliputi mematuhi peraturan; dan (4) hubungan manusia dengan Tuhannya, meliputi bersyukur atas nikmat Tuhan Yang Maha Esa dan berdoa.
\end{abstract}

Kata Kunci : karya sastra, novel, nilai moral.

Abstract. In literary works, one of which is a novel, often the author or writer presents values that can be applied by readers in life, one of which is moral values. Moral value is a measure to judge the good and bad of an act that can be used as a guide for human life. This study aims to describe the analysis of the moral values of Tere Liye's novel Daun Yang Jatuh Tak Henci Angin. This type of research is descriptive qualitative, which means that the author studies and analyzes novels using descriptive methods. The results of this study resulted in several conclusions on the moral values of the novel covering four aspects, namely: (a) human relations with oneself, including admitting mistakes, having a firm stand, sadness, hatred, keeping promises, and being wise; (2) human relations with other humans, including affection, respect for parents, care, love to help, and kindness; (3) human relations with the natural environment, including complying with regulations; and (4) man's relationship with God, which includes being grateful for the blessings of God Almighty and praying.

Keywords: literary works, novels, moral values.

\section{PENDAHULUAN}

Karya sastra merupakan hasil karya seseorang yang dituangkan dalam bentuk bahasa. Dalam karya sastra imajinasi dijabarkan untuk mengungkapkan kenyataan-kenyataan hidup yang dialami oleh tokohnya. Biasanya kehidupan yang ada dalam karya sastra mirip dengan kehidupan nyata, karena karya sastra merupakan adaptasi atas kehidupan lingkungan sekitarnya.

Sebuah karya sastra yang dibuat oleh pengarang, di dalamnya terdapat maksud untuk menyampaikan gagasan, pandangan hidup, tanggapan, tentang kehidupan sekitar secara menarik dan menyenangkan. Selain hal itu, pengarang juga bermaksud menyampaikan nilai-nilai yang memuat keyakinannya yang bermanfaat bagi penikmatnya. Sebuah karya sastra sudah sepatutnya diapresiasi dalam bentuk nilai. Darmadi (2009: 50) berpendapat nilai memiliki segala sesuatu yang disenangi, diinginkan, dicita-citakan, dan disepakati. Nilai berada dalam hati nurani dan pikiran sebagai suatu keyakinan atau kepercayaan.

Kehadiran karya sastra bagi pembacanya adalah untuk meningkatkan harkat dan martabat manusia sebagai makhluk berbudaya, berpikir, dan berketuhanan. Oleh karena itu, dalam penyajian karya sastra hendaknya diiringi dengan nilai moral yang dapat diambil kebaikannya oleh para pembaca. Moral dalam pengertian filsafat merupakan suatu konsep yang telah dirumuskan oleh suatu 


\section{ANALISIS NILAI RELIGIUS DALAM NOVEL RANAH 3 WARNA KARYA AHMAD FUADI DAN RRP KELAS XII}

masyarakat untuk menentukan kebaikan atau keburukan. Moral merupakan suatu norma tentang kehidupan yang telah diberikan kedudukan istimewa dalam kegiatan atau kehidupan sebuah masyarakat. Informasi-informasi yang telah diperoleh dan disertai dengan pengalaman kemudian ia bentuk dalam sebuah kehidupan fiksi berbentuk cerita panjang yang menengahkan tokoh-tokoh dan menampakkan serangkaian peristiwa tokoh-tokoh dan beragam rangkaian cerita, pembaca diharapkan dapat mengambil hikmah dari pesan-pesan yang disampaikan atau diamanatkan. Pengarang berusaha agar pembaca mampu memperoleh nilai-nilai tersebut dan bisa merefleksikannya dalam kehidupan.

Salah satu novel yang menarik untuk dibaca kalangan remaja adalah novel karya Tere Liye. Salah satunya novel yang berjudul Daun Yang Jatuh Tak Pernah Membenci Angin. Fenomena moral dan sosial dalam novel Daun yang Jatuh Tak Pernah Membenci Angin berkaitan erat dengan masalah hubungan antara manusia dengan Tuhan, manusia dengan diri sendiri, dan hubungan antara manusia dengan manusia lain dalam lingkup sosial. Jenis dan wujud pesan moral yang terdapat dalam karya sastra akan bergantung pada keyakinan, keinginan, dan ketertarikan pengarang yang bersangkutan. Jenis dan ajaran moral serta nilai sosial itu sendiri dapat mencakup masalah yang bisa dikatakan bersifat tidak terbatas. Cakupannya meliputi seluruh persoalan hidup dan kehidupan, seluruh persoalan yang menyangkut harkat dan martabat manusia.

Penelitian sebelumnya dilakukan oleh Yuli Astuti- Universitas Sanata Dharma Yogyakarta tahun 2014 dalam skripsinya yang berjudul Nilai-Nilai Moral dalam novel Negeri 5 Menara karya A. Fuadi: Tinjauan Sosiologi Sastra dan Implementasinya pada Pembelajaran Sastra di SMA Kelas XI Semester II. Dalam penelitian Astuti (2014: 102), novel tersebut dikaji dengan pendekatan analisis teks. Data yang dikumpulkan dari unit-unit teks pada novel mencerminkan nilai moral tokoh. Hasil dari penelitian tersebut menghasilkan delapan nilai moral. Kedelapan nilai tersebut diperoleh dari empat kategori nilai moral berikut: Pertama, nilai moral dalam lingkup hubungan manusia dengan Tuhan: religious dan toleransi. Kedua, nilai moral dalam lingkuphubungan manusia dengan diri sendiri: kerja keras, disiplin, dan cinta damai. Ketiga, nilai moral dalam lingkup hubungan manusia dengan sesama: tolong menolong dan bersahabat. Keempat, nilai moral dalam lingkup hubungan manusia dengan lingkungan: peduli lingkungan.
Berdasarkan uraian di atas, peneliti bermaksud untuk melakukan penelitian yang berjudul "Analisis Nilai Moral yang terdapat dalam novel Daun Yang Jatuh Tak Pernah Membenci Angin karya Tere Liye".

\section{METODE PENELITIAN}

Dalam penelitian ini, peneliti menggunakan jenis metode penelitian kualitatif untuk mendeskripsikan hasil dari analisis nilai moral novel Daun Yang Jatuh Tak Pernah Membenci Angin karya Tere Liye.

Sumber data dalam penelitian ini berupa novel Daun Yang Jatuh Tak Pernah Membenci Angin karya Tere Liye. Untuk pengukuran data tersebut peneliti menggunaan teknik studi pustaka, sedangkan untuk teknik pengumpulan data berupa teknik dukumentasi. Teknik ini dilakukan dengan mencatat nilai moral yang ada dalam novel, kemudian data yang telah dipilih digunakan sebagai objek yang akan diteliti. Hasil dari teknik dokumentasi adalah data nilai kejujuran, kesediaan untuk bertanggung jawab, kemandirian moral, dan keberanian moral.

\section{HASIL DAN PEMBAHASAN}

\section{Hasil Penelitian}

Setelah dilakukannya analisis data, dalam novel Daun Yang Jatuh Tak Pernah Membenci Angin ini terdapat beberapa nilai moral yang meliputi, hubungan manusia dengan diri sendiri, hubungan manusia dengan manusia lain, hubungan manusia dengan lingkungan alam, dan hubungan manusia dengan Tuhan.

\begin{tabular}{|c|c|c|}
\hline \begin{tabular}{|l|l|l} 
No & \\
\end{tabular} & Nilai Moral & Halaman \\
\hline \multicolumn{3}{|c|}{ a. Hubungan Manusia Dengan Diri Sendiri } \\
\hline & lengakui Kesalahan & 114 \\
\hline & erpendirian Teguh & 125,125 \\
\hline $3 \mathrm{~s}$ & edih & $61,143,242$ \\
\hline & & 41,39 \\
\hline & lenepati Janji & 87,31 \\
\hline & ijaksana & 30 \\
\hline & yukur & 128,27 \\
\hline & Jaspada & 24 \\
\hline & ercaya Diri & 15 \\
\hline 10 R & indu & 11 \\
\hline \multicolumn{3}{|c|}{ b. Hubungan Manusia Dengan Manusia Lain } \\
\hline & asih Sayang & 17,17 \\
\hline & Nenghormati Orang Tua & 35 \\
\hline & eduli & 179,35 \\
\hline & emar Menolong & 25 \\
\hline & amah & 18,51 \\
\hline \multicolumn{3}{|c|}{ c. Hubungan Manusia Dengan Lingkungan Alam } \\
\hline & lematuhi Peraturan & 221 \\
\hline \multicolumn{3}{|c|}{ d. Hubungan Manusia Dengan Tuhan } \\
\hline & ersukur Atas Nikmat Tuhan Yang Maha Esa & 26 \\
\hline & erdoa & 54,60 \\
\hline
\end{tabular}

Nilai Moral novel Daun Yang Jatuh Tak Pernah Membenci Angin 

AHMAD FUADI DAN RRP KELAS XII

\section{PEMBAHASAN}

Nilai moral Novel Daun Yang Jatuh Tak Pernah Membenci Angin Hubungan Manusia dengan Diri Sendiri Setiap manusia tidak akan lepas dari persoalan terhadap dirinya sendiri. Persoalan tersebut sangat beragam jenis dan tingkatannya. Seperti permasalahan dengan rasa kurang percaya diri, rindu, kesepian, marah, bimbang, dan persoalan lainnya. Hubungan manusia dengan diri sendiri dalam novel Daun Yang Jatuh Tak Pernah Membenci Angin meliputi:

Mengakui Kesalahan

Mengakui kesalahan berarti sadar akan kesalahan yang diperbuat oleh diri sendiri. Dalam novel ini, wujud hubungan manusia dengan diri sendiri yaitu mengakui kesalahan. Hal ini dapat ditemukan pada kutipan.

Aku dulu mungkin keliru. Ya, aku dulu keliru. Kau yang benar, Tania. Kau berhak mengatakan itu kepadanya. Dia tahu atau tidak tahu, terima atau tidak terima, marah atau tidak, benci atau tidak benci, kau berhak mengatakannya, honey. Hakmu jauh lebih besar dibandingkan hak dia, bahkan juga dibandingkan dengan kewajibanmu memastikan pernikahan itu berjalan lancar..." Anne mendekap bahuku. Berbisik lemah. (Liye, 2010:144)

Kutipan tersebut menjelaskan bahwa Anne mengakui kesalahannya karena dulu ia sempat meragukan keputusan Tania untuk mengakui perasaan yang dipendamnya selama ini kepada Danar.

Berpendirian Teguh

Ketika kita bersedih boleh saja menangis tetapi jangan sampai berlarut-larut. Hal tersebut tercermin pada kutipan berikut.

Aku menyeka mataku yang mulai mengembun. Tidak. Aku takkan pernah menangis, Ibu. Walaupun dulu sebelum pergi kau mengizinkan aku untuk menangis demi dia. (Liye, 2010:125)

Kutipan tersebut menjelaskan bahwa Tania kembali berpendirian teguh setelah matanya mengembun menangisi Danar karena kak Ratna kembali menjalin hubungan dengannya.

Sedih

Terdapat pada kutipan:

Hari itu senin. Seminggu sebelum usiaku tepat tiga belas tahun. Adikku delapan tahun. Dan dia dua puluh tujuh. Aku tidak percaya angka tiga belas membawa sial, takdir, sore itu ibuku meninggal. Pergi selama-lamanya dari kami. (Liye, 2010: 61) Kutipan tersebut menjelaskan bahwa hal yang membuat Tania sedih adalah ketika ia sebentar lagi akan berulang tahun tetapi kenyataan pahit terjadi ketika Ibu harus pergi untuk selama-lamanya. Kutipan lain dapat dilihat sebagai berikut:
Tahukah kau, selama ini aku iri padamu, Tania. Setiap melihat wajahmu yang menyenangkan, teman-teman di kelas juga terbawa ikut senang. Aku tak pernah membayangkan punya teman dengan kemampuan mempengaruhi sebesar kau, Tania. Dan tahukah kau saat melihatmu sekarang menangis, hatiku juga seperti ikut tertusuk. Anne mendekapku. Suaranya lemah. Dia menarikku untuk duduk. Mengangkat kepalaku dari balik bantal. (Liye, 2010:143)

Kutipan kedua di atas menjelaskan bahwa sahabat Tania yaitu Anne sangat ikut terpukul melihat keadaan Tania yang tersiksa oleh perasaannya yang tak sanggup mengungkapkan perasaannya kepada Danar. Benci

Terdapat pada kutipan:

Aku menghela napas. Benci sekali dengan pembicaraan itu. Menatap Ibu sirik. Kenapa sih Ibu akrab dengan kak Ratna?. (Liye, 2010: 41)

Kutipan tersebut menjelaskan bahwa Tania sangat tidak menyukai keakraban ibu ketika mengobrol dengan kak Ratna. Kutipan rasa benci juga dapat dijumpai pada kutipan berikut:

Seketika hati kecilku tidak terima. Sakit hati! Bukankah selama ini kalau kami pergi entah ke mana, akulah yang lengannya digenggam? Akulah yang pundaknya dipegang? Akulah yang kepalanya diusap. Itu jelas-jelas posisiku! Aku benci sekali. (Liye, 2010: 39)

Menepati Janji

Terdapat pada kutipan:

Meskipun aku mengotot sampai mampus hendak melanjutkan sekolah di Jakarta saja, dia pasti akan menolak mentah-mentah. Dan karena aku sudah berjanji akan selalu menuruti semua kata-katanya, maka daripada berdebat, dengan sukarela aku berangkat ke Singapura. (Liye, 2010: 87)

Kutipan tersebut menjelaskan bahwa dia akan pergi ke Singapura dengan sukarela karena sudah berjanji kepada dia. Sikap menepati janji juga dapat ditemukan pada kutipan berikut.

Bijaksana

Terdapat pada kutipan:

Ibu bekerja serabutan, apa saja yang bisa dikerjakan, dikerjakan. Sayang, Ibu lebih banyak sakitnya. Semakin lama semakin parah. Kata orang-orang yang membuat parah sakit Ibu bukan semata-mata karena fisiknya, lebih karena beban pikirannya. Aku tak tahu pasti apakah itu benar. Yang pasti dan benar akhirnya Aku dan Dede terpakasa bekerja: menjadi pengamen. Membawa kencrengan dari tutup botol. Menyanyikan lagu-lagu dewasa. Berangkat pagi-pagi pulang malam-malam. Ditempa kehidupan jalanan. (Liye, 2010: 30) 


\section{Wandi Setiawan, Tanti Agustiani, David Setiadi \\ ANALISIS NILAI RELIGIUS DALAM NOVEL RANAH 3 WARNA KARYA AHMAD FUADI DAN RRP KELAS XII}

Kutipan tersebut menjelaskan bahwa dalam usia Tania dan Dede yang masih belia mereka rela untuk memutuskan bekerja untuk memenuhi kelangsungan hidupnya menggantikan Ibu yang sedang sakit.

Syukur

Terdapat pada kutipan:

Terima kasih, Tuhan. (Liye, 2010: 128)

Kutipan tersebut menjelaskan bahwa dia bersyukur kepada Tuhan. Kutipan lain yang menunjukkan rasa syukur dapat dilihat pada kutipan berikut.

Dia benar-benar menjadi malaikat kami. Demi melihat kebahagiaan di rona muka Ibu, malam itu seketika aku berikrar dalam hati. Bersumpah! Dia akan selalu menjadi orang yang kuhormati setelah Ibu. Selalu. ( Liye, 2010: 27).

Setelah oom Danar memutuskan untuk menyekolahkan Tania dan Dede, Tania berikrar di dalam hati bahwa ia akan selalu menghormati Danar setelah Ibu.

Waspada

Terdapat pada kutipan:

Aku dan Dede harus kembali bekerja, meskipun dengan kaki pincang. Sebenarnya luka itu tidak serius. Aku hanya takut menginjakkan bagian yang luka. Takut berdarah lagi. (Liye, 2010: 24).

Kutipan tersebut menjelaskan bahwa dia berhati-hati untuk kembali bekerja karena ia takut menginjakkan bagian kakinya yang terluka berdarah lagi.

Percaya Diri

Setiap individu harus mempunyai sifat percaya diri. Percaya diri merupakan pengakuan terhadap kelebihan diri sendiri. Seperti terdapat pada kutipan novel berikut: Aku tahu aku cantik. Tubuhku proporsional. Rambut hitam legam nan panjang. (Liye, 2010: 15)

Kutipan di atas menjelaskan bahwa Tania yang percaya diri terhadap fisiknya, ia memiliki wajah cantik, rambut hitam legam nan panjang.

Rindu

Terdapat pada kutipan:

Setiap malam aku datang ke toko buku ini.

Aku membeli satu buku setiap kali ke sini. Bukan buku yang hendak kubaca. Anggap saja sebagai tiket harga masuk karena telah menggunakan lantai dua mereka sebagai tempat menumpahkan segala perasaan. Tempatku terpekur mengenang segalanya. Semua masa lalu itu. (Liye, 2010: 11)

Hubungan Manusia dengan Manusia lain Berbuat hormat kepada orang lain merupakan suatu dasar dalam hidup sosial, baik antar kelompok maupun intra kelompok. Sikap hormat kepada orang lain merupakan suatu kaidah untuk dapat hidup bersama dalam masyarakat. Selain sebagai makhluk pribadi, manusia juga merupakan makhluk sosial yang selalu berinteraksi dengan lingkungannya. Manusia dilahirkan ke dunia dalam kondisi lemah tak berdaya. Manusia tidak bisa hidup sendirian tanpa bantuan orang lain. (Magnis-Suseno, 2001: 34).

Berdasarkan pendapat ahli, manusia merupakan makhluk bersosial yang tidak dapat hidup sendiri. Maka dari itu, secara moral manusia perlu menjaga hubungan baik dengan sesamana guna membuat kehidupan bermasyarakat menjadi hangat dan nyaman. Pada wujud nilai moral dalam novel Daun Yang Jatuh Tak Pernah Membenci Angin ini dapat dilihat pada perwujudan berikut.

Kasih sayang

Terdapat pada kutipan:

Kata Ibu, "Tania, hati-hatilah di sana! Kita harus mengganti setiap barang yang rusak karena kita sentuh! Jaga adikmu, jangan nakal. (Liye, 2010: 17)

Kutipan tersebut menjelaskan bahwa Ibu memberi nasihat kepada Tania untuk berhat-hati. Dapat juga dilihat pada kutipan berikut:

Sore itu, Ibu menggosok tubuh hitam dekilku. Menggunakan sampo banyakbanyak di rambutku yang mengkriting dan bau karena terkena sinar matahari seharian. Begitu juga dengan Dede.Ibu memberikan pakaian terbaik yang disimpannya dalam bulatan plastik di atas para-para kardus. (Liye, 2010: 17).

Kutipan tersebut memperlihatkan bahwa betapa Ibu sangat menyayangi anakanaknya. Ibu menunjukkan rasa kasih sayang terhadap anak-anaknya dengan memandikan mereka dan memberikan pakaian terbaik yang disimpannya dalam bulatan plastik.

Menghormati Orang Tua

Salah satu cerminan manusia yang menjunjung nilai kesopanan adalah dengan menghormati orang tua dengan tidak memandang pangkat atau apapun. Dalam novel ini menceritakan bahwa Danar selalu menyalami Ibu dengan mencium tangannya. Hal tersebut terdapat pada kutipan.

Dia hanya tertawa. Mengelus rambutku. Pura-pura meninju bahu adikku. Kemudian menyalami Ibu. Tahukah kalian, dia selalu mencium tangan Ibu. Amat hormat pada Ibu. (Liye, 2010: 35)

Peduli

Terdapat pada kutipan:

Aku menatap ekor barongsai di salah satu bangunan kelenteng. Merah menyala. Semua itu tinggal masa lalu. "Bagaimana kabar kak Danar?" cepat atau lambat aku pasti menanyakannya, kan? Jadi lebih baik dibahas secepat mungkin. (Liye, 2010:179)

Kutipan tersebut menjelaskan bahwa dia menanyakan kabar kak Danar 


\section{ANALISIS NILAI RELIGIUS DALAM NOVEL RANAH 3 WARNA KARYA AHMAD FUADI DAN RRP KELAS XII}

sebagai bentuk kepedulian terhadap orang lain. Kutipan lain yaitu:

Dia rajin dua kali singgah sebentar di kontrakkan baru. Membawakan makanan, buku-buku untukku, dan permainan buat adikku. Aku dan Dede selalu menunggu kunjungan tersebut. Duduk di depan kontrakkan menatap kelokan gang. Menunggu jadwal kedatangannya setiap selasa dan jumat malam. Berseru senang saat siluet tubuhnya terlihat di ujung gang. Lantas berlari-lari menyambutnya. (Liye, 2010: 35)

Gemar menolong

Terdapat pada kutipan:

Dia mengeluarkan dua kotak. Melambaikan tangan meminta kami mendekat. Aku dan Dede melangkah ke arahnya, berdiri di depan kursinya, urung memulai pertunjukkan kencrengan tutup botol. Dede malah memasukkan alat musik ke saku celana. Lagi-lagi menguap. Kotak itu ternyata berisi dua pasang sepatu baru. "pakailah!”. (Liye, 2010:25)

Kutipan tersebut menjelaskan bahwa dia sedang menolong seseorang dengan memberikan sepatu untuk Tania dan Dede.

Ramah

Terdapat pada kutipan:

Adikku Dede tersipu malu saat dipuji oleh dia ("Lihatlah! Ternyata kau keren sekali"). Aku juga malu-malu dengan "penampilan baru” itu ("Dan kau cantik sekali, Tania!”). (Liye, 2010: 18)

Kutipan tersebut menjelaskan bahwa mereka merasa malu dengan penampilan barunya karena dipuji oleh dia yang ramah. Kutipan lain yaitu:

Seorang mbak-mbak penjaga rak buku lewat di depanku. Menegur (ingin lewat di depanku). Aku tersenyum seadanya. Beranjak setengah langkah mundur. Memberi celah baginya. Mbak itu tersenyum. ("Terima kasih"). (Liye, 2010: 51)

Hubungan Manusia dengan Lingkungan Alam

Menurut Magnis-Suseno (2001: 34) berbuat hormat kepada orang lain merupakan suatu dasar dalam hidup sosial, baik antar kelompok maupun intra kelompok. Sikap hormat kepada orang lain merupakan suatu kaidah untuk dapat hidup bersama dalam masyarakat. Pendapat tersebut menjelaskan bahwa nilai moral hubungan manusia dengan lingkungan memiliki arti yang sama dengan nilai moral hubungan manusia dengan sesama.

Pada dasarnya, lingkungan hidup manusia terdiri dari dua jenis lingkungan, yakni lingkungan alam, dan lingkungan sosial. Hubungan dengan lingkungan sangat dibutuhkan manusia sebagai bentuk penyesuaian diri untuk bertahan hidup. Mematuhi Peraturan

Mematuhi peraturan berarti membudayakan ketertiban. Nilai mematuhi peraturan dalam novel disampaikan kepada pembaca bagaimana seharusnya suatu peraturan disikapi. Nilai mematuhi peraturan ditunjukkan pada kutipan berikut. Lampu itu setia. Dan penduduk kota ini juga setia mengikuti petunjuk tersebut. Tak ada yang nekat menerobos meskipun jalanan amat lenggang. Semua menunggu saatnya. Menunggu masanya. Sabar. (Liye, 2010: 221)

Kutipan di atas memperlihatkan kejadian di mana semua orang dapat mematuhi peraturan saat berkendara. Hal tersebut merupakan hal baik yang patut ditiru dalam kehidupan sehari-hari.

3) Hubungan Manusia dengan Tuhannya

Hubungan manusia dengan Tuhan merupakan hubungan vertikal yang menghubungkan antara manusia dengan penciptanya. Tuhan sebagai tempat bergantung bagi semua ciptaan-Nya. Dalam novel ini hubungan manusia dengan Tuhan yaitu bersyukur atas nikmat Tuhan Yang Maha Esa dan berdoa. Di bawah ini merupakan penjelasan hubungan manusia dengan Tuhan.

Bersyukur atas Nikmat Tuhan yang Maha Esa

Salah satu wujud syukur kepada Tuhan dapat diwujudkan melalui perkataan dan perbuatan. Dalam novel ini, tersirat gambaran perasaan tokoh yang mencerminkan rasa bersyukur kepada Tuhan. Berikut kutipan yang menunjukkan rasa bersyukur kepada Tuhan.

Dan sungguh Tuhan, aku tidak tahu apakah itu kabar baik atau buruk, ternyata Engkau mendengarnya. (Liye, 2010: 26)

Kutipan tersebut menjelaskan bahwa dia bersyukur atas apapun yang didapatnya entah itu kabar baik atau buruk. Berdoa

Setiap manusia apabila meyakini adanya Tuhan berarti hal tersebut termasuk ke dalam kategori hubungan manusia dengan Tuhan. Salah satu hal tersebut dapat diwujudkan melalui berdoa. Berdoa merupakan sarana komunikasi dengan Tuhan. Dalam novel Daun Yang Jatuh Tak Pernah Membenci Angin ditunjukkan pada tokoh utama yang berdoa secara berulang akan kesembuhan Ibunya. Terdapat pada kutipan:

Ya Tuhan, Aku tak bisa membayangkan apa yang terjadi jika Ibu tidak kunjung sembuh. Dalam doa-doa aku hanya menyebut kesembuhan Ibu. Aku tak ingin kehilangannya. Lihatlah apa yang terjadi kalau dia pergi. Aku sering menangis sambil 
memeluk tubuh Ibu yang semakin kecil. (Liye, 2010: 54)

Berdoa merupakan kegiatan yang tidak boleh dilewatkan oleh manusia dan harus dilakukan berulang. Kutipan di atas memperlihatkan di mana tokoh utama mengucap doa yang sama, hal tersebut termasuk ke dalam hubungan manusia dengan Tuhan.

\title{
SIMPULAN
}

\begin{abstract}
Nilai moral yang terdapat dalam novel Daun Yang Jatuh Tak Pernah Membenci Angin karya Tere Liye, terdiri dari empat aspek 1) hubungan manusia dengan diri sendiri mencakup: mengakui kesalahan, berendirian teguh, sedih, benci, menepati janji, bijaksana, syukur, waspada, percaya diri, dan rindu. 2) hubungan manusia dengan manusia lain mencakup: kasih sayang, menghormati orang tua, peduli, gemar menolong, dan ramah. 3) hubungan manusia dengan lingkungan mencakup: mematuhi peraturan, dan 4) hubungan manusia dengan Tuhan mencakup: bersyukur atas nikmat Tuhan dan berdoa.
\end{abstract}

\section{SARAN}

Melihat banyak sekali kekurangan dalam penelitian ini, maka peneliti menyarankan kepada peneliti lain untuk lebih mendalami novel Daun Yang Jatuh Tak Pernah Membenci Angin, baik dari segi nilai moral maupun lainnya. Karena sangat baik diterapkan khususnya kepada peserta didik selain sebagai upaya peningkatan budaya literasi juga sebagai pendidikan karakter bagi peserta didik. Peneliti juga berharap, penelitian ini bisa menjadi referensi bagi peneliti selanjutnya.

\section{DAFTAR PUSTAKA}

Astuti, Yuli. (2014). Nilai-Nilai Moral dalam novel Negeri 5 Menara karya A. Fuadi: Tinjauan Sosiologi Sastra dan Implementasinya pada Pembelajaran Sastra di SMA Kelas XI Semester II.

Liye, Tere. 2010. Daun Yang Jatuh Tak Pernah Membenci Angin. Jakarta: Gramedia Pustaka Utama

Sugiyono. 2015. Metode Penelitian Pendidikan Pendekatan Kuantitatif,Kualitatif, dan $R \& D$. Bandung: Alfabeta. 